\title{
Establishment and Properties of the Continuous Cell Line Derived from the Embryonated Eggs of Chum Salmon, Oncorhynchus keta*1
}

\author{
Tasuku Watanabe*2, Masayasu SANo*2, Yoshifumi ISHIDA*2, \\ Yuko MizuSAWA ${ }^{* 2}$, and Masanori MichIKAWA ${ }^{* 2}$
}

(Received June 16, 1980)

\begin{abstract}
A continuous cell line was established from the embryonated eggs of chum salmon, Oncorhynchus keta, using conditioned medium, the filtered supernatant of rainbow trout gonadal cell line, RTG-2. It took 10 days in primary culture, 87 and 25 days in secondary and tertiary culture, respectively, and 7-10 days since fourth culture to form confluent cell sheets at $20^{\circ} \mathrm{C}$. The cell line, designated SE, has been subcultured 150 times over the period of 3 years.

The cell line consists of fibroblastic spindle shaped cells and multiplies in an unrestrained fashion to form piled up colonies. Electron microscopically, desmosomes were often seen between two adjacent cells. And, numerous mitochondria were observed arround nuclei. The chromosome number of the cells was ranging from 53 to 79 . This cell line has very wide permissible temperature range of $4-25^{\circ} \mathrm{C}$ for growth.

SE cells had the lowest sensitivity to infectious pancreatic nectosis virus in four tested salmonid cell lines, RTG-2, YNK, SE, and IK, which was originally established from the kidney of Iwana, Salvelinus leucomaenis, in our laboratory. And SE cells had as much sensitivity against infectious hematopoietic necrosis virus as those of RTG-2 and YNK cells.
\end{abstract}

Recently viral diseases of salmonid fishes have been frequently reported ${ }^{1-10)}$. Thus, several cell lines have been established from salmonid fish tissues for the purpose of the detection and isolation of virus from diseased fishes, and of the studies of virus-host relationships ${ }^{11-16)}$. But, the relation has not been clear between salmonid fish viral diseases and chum salmon, Oncorhynchus keta, one of the most important species in the fisheries of Japan. This report describes the establishment of the cell line derived from the embryonated eggs of chum salmon, some cytological characteristics, and susceptibilities of the line to two salmonid fish viruses, infectious pancreatic necrosis (IPN) virus and infectious hematopoietic necrosis (IHN) virus.

\section{Materials and Methods}

Cells

Cells were grown and maintained in Eagle's minimum essential medium (EMEM) supplemented with $10 \%$ fetal calf serum (FCS) and containing $100 \mu \mathrm{g}$ of kanamycin sulfate per $\mathrm{m} l$ and 1
mM of Tris- $\mathrm{HCl}$ buffer at $20^{\circ} \mathrm{C}$. The cells included rainbow trout Salmo gairdnerii gonadal cell line, RTG-2 ${ }^{11)}$, and the Yamame $O$. masou kidney derived cell line, $Y_{N K}{ }^{18)}$. Iwana fibroblastic cell line, IK, was established from the kidney tissues of Iwana, Salvelinus leucomaenis, in the manner used in the establishment of YNK cell line in this laboratory. This cell line has been subcultured 150 times since its initiation in October, 1976. And the cells are diploid with 59 chromosomes in colchicine metaphase.

\section{Primary Culture}

The embryonated eggs of chum salmon were kindly provided by Mr. T. Marwa, Otsuchi-cho Salmon Hatchery, Iwate. The eggs, 1-3 days prior to hatching, were disinfected with dipping for several minutes in $70 \%$ ethanol, and were transferred in the sterilized glass dish after wiped the ethanol away courteously with sterilized gauzes. The embryos, after the removal of egg membranes and yolks, were minced into small fragments with scissors in small amount of $0.25 \%$ trypsin- $0.02 \%$ ethylene diamine tetra-acetic acid (EDTA) desolved

*1 The outline of this report was presented at the Annual Meeting of the Japanese Society of Scientific Fisheries, Hakodate, Japan, October, 1979.

*2 School of Fisheries Sciences, Kitasato University, Okirai, Sanriku, Iwate 022-01 (㳊辺 翟 - 佐野正安 • 石田義文・水沢裕子・道川正則：北里大学水産学部). 
in Dulbecco's phosphate buffered saline (PBS) without $\mathrm{Mg}^{++}$and $\mathrm{Ca}^{++}$at room temperature. The cells and fragments were suspended in the conditioned medium, the filtered supernatant of RTG2 cell culture, previously described ${ }^{15)}$, at the density of $10^{5}$ cells per $\mathrm{m} l$ and seeded in $25 \mathrm{~cm}^{2}$ plastic tissue culture flasks (Falcon Plastics, California, U.S.A.), and cultivated at $20^{\circ} \mathrm{C}$.

\section{Chromosome Number}

The cells cultivated on glass cover slips were reacted with $0.0025 \%$ colchicine in EMEM supplemented with $10 \%$ FCS, then, washed with $10 \mathrm{mM} \mathrm{CaCl}_{2}$ hypotonic solution, fixed with $25 \%$ acetic acid- $75 \%$ ethanol, and stained with $0.75 \%$ Dahria violet.

\section{Virus Infectivity Assays}

IPN virus, isolated from a rainbow trout, and IHN virus, isolated from a Yamame, both of which were described in previous paper ${ }^{18)}$, were used in this study. The infectivities of the viruses on RTC-2 cells, YNK cells, IK cells, and SE cells were titrated by the end point dilution method in microcultureplates (Cooke Laboratory Products, Virginia, U.S.A.) as described elsewhere ${ }^{1 \theta)}$.

\section{Electron Microscopy}

The normal and virus-infected cells cultured on Falcon 3002 plastic tissue culture dishes were fixed with $2.5 \%$ glutaraldehyde in $0.1 \mathrm{M}$ phosphate buffer ( $\mathrm{pH} \mathrm{7.3)} \mathrm{for} 2$ hours, and washed in 5\% sucrose-phosphate buffer after scraped from the surface of the dishes. The cells were postfixed with $1 \%$ osmium tetroxide for 1 hour and embedded in Epon 812 after dehydration in graded alcohols. Sections were stained with uranyl acetate and lead citrate, and examined with the JEM $100 \mathrm{~S}$ electron microscope.

\section{Results}

\section{Establishment of SE Cell Line}

After 24 hours' incubation of the primary culture of trypsinized chum salmon embryos, many cells and fragments of tissues were attached on the surface of tissue culture flasks. Culture media were routinely exchanged at the interval of 4 days. Although at the fifth day large cells with many filaments were grown dominantly on the flask surface (Fig. 1, arrow), epithelial cells with one or two nuclei were rapidly grown after 7 th day (Fig. 1, below), and formed monolayer cell sheets at the tenth day of primary culture. The cells were trypsinized and reseeded in two plastic culture flasks. It took 3 or $\mathbf{4}$ days to form confluent cell sheets in secondary culture, but, the cells did not attach on newly used flasks, when transferred to tertiary culture. Consequently, the passage period of secondary culture took 87 days as shown in Table 1. In this period the morphology of cells altered from epitherial square shape to fibroblastic spindle shape.

In a flask of tertiary culture transferred from a secondary culture flask at the 87th day of culture, the cells attached on the flask surface and multiplied so slowly that it took 25 days to form a confluent cell sheet. Since then, the confluent cell sheets of fibroblastic cells were achieved constantly in 7-10 days after seeding of about $10^{8.8}$ cells per flask The cells were cultivated with conditioned medium from primary to fourth culture. In subsequent cultures no decrease of growth was observed with fresh medium. This cell line was designated $\mathrm{SE}$ associated with the in vitro cultured cell line derived from chum salmon emblyonated eggs, as has been subcultured 150 times since its initiation in February, 1977.

\section{Morphology of SE Cells}

SE cell line consists of fibroblastic spindleshaped cells with a small oval nucleus and a few large round, epitherial cells with two or more round nuclei (Fig. 2). The cells grow in the manner of contact inhibited monolayer until the formation of confluent cell sheets, and then, multiply in an unrestrained fashion to form piled up colonies which are easily distinguished with naked eyes from the background of monolayer cells when stained with Giemsa (Fig. 3). With phase contrast microscope, the cells have round or oval nuclei with one or two nucleoli, and the number of granular intracytoplasmic organellas around nucleus (Fig. 4).

Electron microscopically, most of SE cells were spindle-shaped with an elongated nucleus often deeply indented (Fig. 5a). The cytoplasm had numerous ribosomes, bundles of fibrils, and mitochondria around nucleus (Fig. 5b). Other intracytoplasmic organellas were poorly developed. Desmosomes were often seen between two adjacent cells (Fig. 5c).

\section{Temperature Range for Growth}

The cell line grew at the temperature between $4-25^{\circ} \mathrm{C}$ as shown in Table 2. But, at high temperature over $30^{\circ} \mathrm{C}$, all of cells came off from the surface of tissue culture tubes within 14 days. The cells grew most rapidly at the temperature between 
Tahle 1. Successive cultivation of chum salmon embryo derived cells

\begin{tabular}{lcc}
\hline Passage* & $\begin{array}{c}\text { Days for } \\
\text { confluent cell } \\
\text { sheet formation }\end{array}$ & Culture media \\
\hline Primary & 10 & $\begin{array}{c}\text { Conditioned } \\
\text { medium }\end{array}$ \\
2nd. & 87 & $"$ \\
3rd. & 25 & $"$ \\
4th. & $7-10$ & Fresh medium \\
\hline * About 105.5 cells were seeded on each $25 \mathrm{~cm}^{2}$ Falcon tissue \\
culture flasks and incubated at $20^{\circ} \mathrm{C}$.
\end{tabular}

Table 2. The influence of incubation temperature on the growth of SE cells

\begin{tabular}{lrrrrrrr}
\hline Temperature $\left({ }^{\circ} \mathrm{C}\right)$ & 4 & 10 & 15 & 20 & 25 & 30 \\
\hline $\begin{array}{l}\text { Days for the formation } \\
\text { of confluent cell sheets* }\end{array}$ & 30 & 17 & 8 & 8 & 13 & - \\
\hline $10^{5}$ cells were seeded on each glass tissue culture tubes.
\end{tabular}

$15^{\circ} \mathrm{C}$ and $20^{\circ} \mathrm{C}$, and at $4^{\circ} \mathrm{C}$ grew too slowly to need one month to form confluent cell sheets when seeded $10^{5}$ cells per glass tissue culture tube.

\section{Chromosome Number}

Chromosome number of SE cells, as shown in Text-Fig. 1, was ranging from 53 to 79 . Count were made on 97 cells and $76 \%$ of them were between 58 and 67 . The cells with 62 chromosomes were frequently observed and occupied $14 \%$ of counted cells. Occasionally, tetraploid-like cells with about 120 chromosomes were observed.

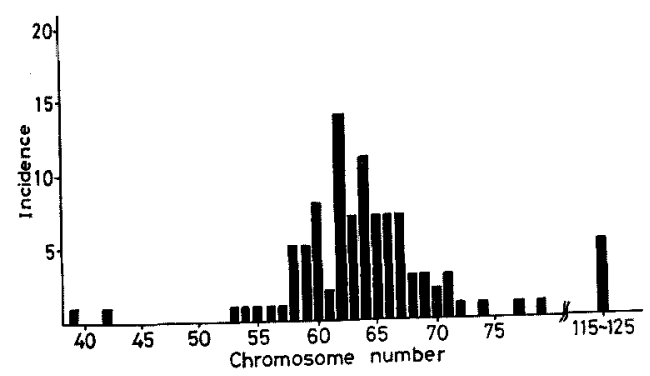

Text-Fig. 1. Chromosome numbers of SE cells in colchicine metaphase.

\section{Susceptibility to Fish Viruses}

Infectivities of two salmonid fish viruses were compared on four cell line, RTG-2 derived from rainbow trout gonadal tissue, YNK from Yamame kidney, IK from Iwana kidney, and SE from chum. salmon embryonated eggs. As shown in Table 3, the cytopathic effect (CPE) of IPN virus was ob- served at the second day of infection on three cells and at the third day on SE cells, when inoculated with the virus at input multiplicities of more than one $50 \%$ infectious doses (TCID 50 ) per cell. YNK cells was most sensitive to the virus in this experiment. And SE cells had the lowest sensitivy in tested four cell lines to IPN virus. The titres of the virus stocks on four cells were $10^{6.3}$ (RTG-2), $10^{7.3}$ (YNK), $10^{6.8}$ (IK), and $10^{6.0}$ (SE) TCID $_{50}$ per $\mathrm{m} l$, respectively, after two weeks observation. The appearance of the CPE of IPN virus-infected SE cells was similar to those in RTG-2 cells and YNK cells with narrow and elongated cell shape and picnotic nuclei (Fig. 6). Electron microscopically, the aggregation of IPN virus particles was often observed in the cytoplasm of the virus infected SE cells.

Table 3. Susceptibilities of four salmonid fish cell lines against IPN virus and IHN virus

\begin{tabular}{|c|c|c|c|c|c|}
\hline \multirow{2}{*}{$\begin{array}{c}\text { Virus } \\
\text { inoculated }\end{array}$} & \multirow{2}{*}{$\begin{array}{l}\text { Days after } \\
\text { inoculation }\end{array}$} & \multicolumn{4}{|c|}{$\begin{array}{l}\text { Virus titre }\left(\log _{10} \text { TCID }_{50} /\right. \\
\mathrm{m} l) \text { on }\end{array}$} \\
\hline & & RTG-2 & YNK & IK & $\mathrm{SE}$ \\
\hline \multirow[t]{3}{*}{ IPN virus } & 2 & 1.6 & 4.3 & 2.8 & - \\
\hline & 4 & 5.5 & 5.8 & 6.6 & 5.8 \\
\hline & 7 & 6.3 & 7.3 & 6.6 & 6.0 \\
\hline \multirow[t]{3}{*}{ IHN virus } & 2 & 2.6 & 3.8 & 3.3 & 2.8 \\
\hline & 4 & 4.8 & 6.0 & 4.8 & 4.8 \\
\hline & 7 & 5.8 & 6.0 & 5.8 & 5.6 \\
\hline
\end{tabular}

IHN virus had similar infectivity on four salmonid cell lines as shown in Table 3 . The CPE of the virus was observed at the second day of inoculation in the microculture cups of four cells infected with the virus at higher input multiplicities than about one $\operatorname{TCID}_{\mathrm{B} 0}$ per cell. The titres of IHN virus stocks on RTG-2, YNK, IK, and $\mathrm{SE}$ cells were $10^{5.8}, 10^{6.0}, 10^{5.8}$, and $10^{5.6}$ $\mathrm{TCID}_{\text {so }}$ per $\mathrm{m} l$, respectively, after 14 days observation. The degenerative changes of IHN virusinfected SE cells appeared as same as those of RTG-2 cells and YNK cells, characterized with round cell shape and thicker nuclear membrane (Fig. 7). With electron microscope, numerous bullet-shaped IHN virus particles were observed in the intercellular space of the virus-infected $\mathrm{SE}$ cells.

\section{Discussion}

The cells from embryonated eggs of chum salmon adapted to in vitro condition and grew rapidly. It is well known that the cells from 
embryonated tissues are able to grow more easily in tissue culture condition than those from neonatal or more aged animals. This cells were derived from the epithelium of chum salmon embryo because of the prominent desmosomes between adjacent cells, though they grow in manner of fibroblastic monolayer. As often are observed small number of large epithelial-like cells, this cell line consists of two or more cells of different tissue origin. The cells, electron microscopically, have deeply indented nuclei and poorly developed intracytoplasmic organellas except mitochondria, and grow forming piled-up colonies from the surface of culture bottles. And chromosome number of the cells was widely ranging from 53 to 79 , whereas the chromosome number of chum salmon is known to be $74^{17)}$. Those facts indicate that the cell line, SE, was derived from the undifferentiated epithelium of chum salmon embryos.

In our experiment, SE cells had the lowest susceptibilities to IPN virus and IHN virus in four salmonid fish cell lines examined. Salmonid fish cell lines are known to have high sensitivities to IPN virus ${ }^{8,14)}$, while FHM cells, derived from the fathead minnow, Pimephales promelas, have poor sensitivity to the virus ${ }^{10)}$. And the high susceptibility of YNK cells is supposed to depend on the cell origin, derived from the target cells of the virus $^{(6)}$. IHN virus has also high infectivity to salmonid fish cell lines ${ }^{14,18)}$. A chinook salmon derived cell line has different sensitivities to some strains of IHN virus ${ }^{13}$. Although FHM cells are known to be more sensitive to the virus than RTG-2 cells ${ }^{18)}$, it is reported that the virus isolated from rainbow trout in Montana, U.S.A., and replicated in RTG-2 cells replicated poorly in FHM cells and BB cells, derived from brown bullhead, Ictalurus neblosus ${ }^{4}$. Those facts indicate that the infectivities of viruses to different tissue culture cells are not only dependent upon virus strains but also on the origin of viruses, the cells used for isolation and replication, and cell origin, target or not of viruses. The development of such cell lines as SE cells would facilitate the investigation of virus-host relationships in salmonid fishes.

Fijan and GroRgetti reported significant amounts of IPN virus isolated from the living eyed eggs of rainbow trout ${ }^{10)}$. Thus, it is suggested that the low sensitivity of SE cells to the virus are dependent on the origin of the line, the undifferentiated embryonal cells. IK cells have as high sensitivities to both of IPN virus and IHN virus as those of RTG-2 cells, though Iwana has not been known of the occurence of viral diseases. The relationships between the viruses and host cells in our in vitro experiments show no agreement with in vivo and field information. Further investigations are required to examine the antigenic variations of viruses replicated in salmonid fish cell lines, as it is known that IPN virus replicated in FHM cells differs antigenically from the virus replicated in RTG-2 cells ${ }^{18}$.

We are gratefull to Mr. T. MAIWA and members of the staff of Otsuchi-cho Salmon Hatchery for suppling us with eyed eggs of chum salmon.

\section{References}

1) T. SANo: Bull. Japan. Soc. Sci. Fish., 37, 495503 (1971).

2) P. E. Vestergård-Jørgensen and A. MeyLing: Arch. gesamte Virusforsch., 36, 115-122 (1972).

3) K. Wolf, M. C. Qummi, L. L. Petruohn, and M. L. Landolt: J. Fish. Res. Board Can., 30, 1625-1627 (1973).

4) J. E. Holway and C.E. Smith: J. Wildlife Diseases, 9, 287-290 (1973).

5) T. Sano and T. Yamazaki: Bull. Japan. Soc. Sci. Fish., 39, 477-480 (1973).

6) T. Yамamoto: J. Fish. Res. Board Can., 31, 397-402 (1974).

7) K. Wolf, T. Sano, and T. KImura: Fish Disease Leaflet, 44, 1-8 (1975).

8) H.-J. Schlotfeld and J. W. Frost: Berl. Münch. Tierärztl. Wschr., 88, 454 (1975).

9) T. Sano: Fish Pathol., 10, 221-226 (1976).

10) N. N. Fisan and G. Giorgetri: J. Fish Diseases, 1, 269-270 (1978).

11) K. Wolf and M.C. QuimbY: Science, 135, 1065-1066 (1962).

12) J. K. Fryer, A. Yusha, and K. S. PllCher: Ann. N. Y. Acad. Sci., 126, 566-586 (1965).

13) B. B. MCCAIN, J. L. FrYer, and K. S. PILChER: Proc. Soc. Exp. Biol. Med., 137, 1042-1046 (1971).

14) B. L. Nicholson and C. Byrne: J. Fish. Res. Board Can., 30, 913-916 (1973).

15) T. Watanabe, N. Kobayashi, Y. Sato, and Y. IsHIZAKI: Bull. Japan. Soc. Sci. Fish., 44, 415418 (1978).

16) T. Watanabe, K. Tanaka, O. Tamura, Y. Nakagawa, and K. Takahashi: Bull. Japan. Soc. Sci. Fish., 46, 401-406 (1980).

17) M. Sasaki, S. Hitotsumach, S. Makino, and T. TERAo: Caryogia, 21, 389-394 (1968).

18) D. F. AMEND, W. T. Yasutake, and R.W. MEAD: Trans. Amer. Fish. Soc., 98, 796-804 (1969).

19) B. L. Nicholson, G. W. Thorne, C. JANickr, and A. Hanson: J. Fish Diseases, 2, 367-379 (1979). 


\section{Explanation of Plates}

Fig. 1. Phase contrast photomicrograph of the primary culture of chum salmon embryonated eggs 7 days after incubation. Note large cells with many filaments (arrow) and epithelial cells (below). $\times 300$.

Fig. 2. SE cell line, 94th passage, showing spindle-shaped fibroblastic cell sheet. Note large round epithelial cells with two or more round nuclei (arrows). Giemsa stain. $\times 240$.

Fig. 3. A piled up coloney of SE cells. Giemsa stain. $\times 50$.

Fig. 4. Phase contrast photomicrograph of 117 th passage of SE cells consists of many fibroblastic spindle-shaped cells and a small number of large epithelial cells. Note numerous granular intracytoplasmic organellas around nucleus. $\times 300$.

Fig. 5. Electron micrograph of SE cells. a) A spindle-shaped typical SE cell showing an elongated and indented nucleus. $\times 8,500 . \quad b$ ) High magnification of left insertion of Fig. 5a showing 4 mitochondria beside a nucleus. $\times 50,000, c$ ) High magnification of the right insertion of Fig. 5a showing a desmosome between adjacent cells. $\times 50,000$.

Fig. 6. Degenerative changes occurring in SE cells infected with IPN virus, showing elongated cell shape and picnotic nuclei. Giemsa stain. $\times 240$.

Fig. 7. Degenerative changes occurring in SE cells infected with IHN virus, showing round cell shape and thicker nuclear membrane. Giemsa stain. $\times 240$. 

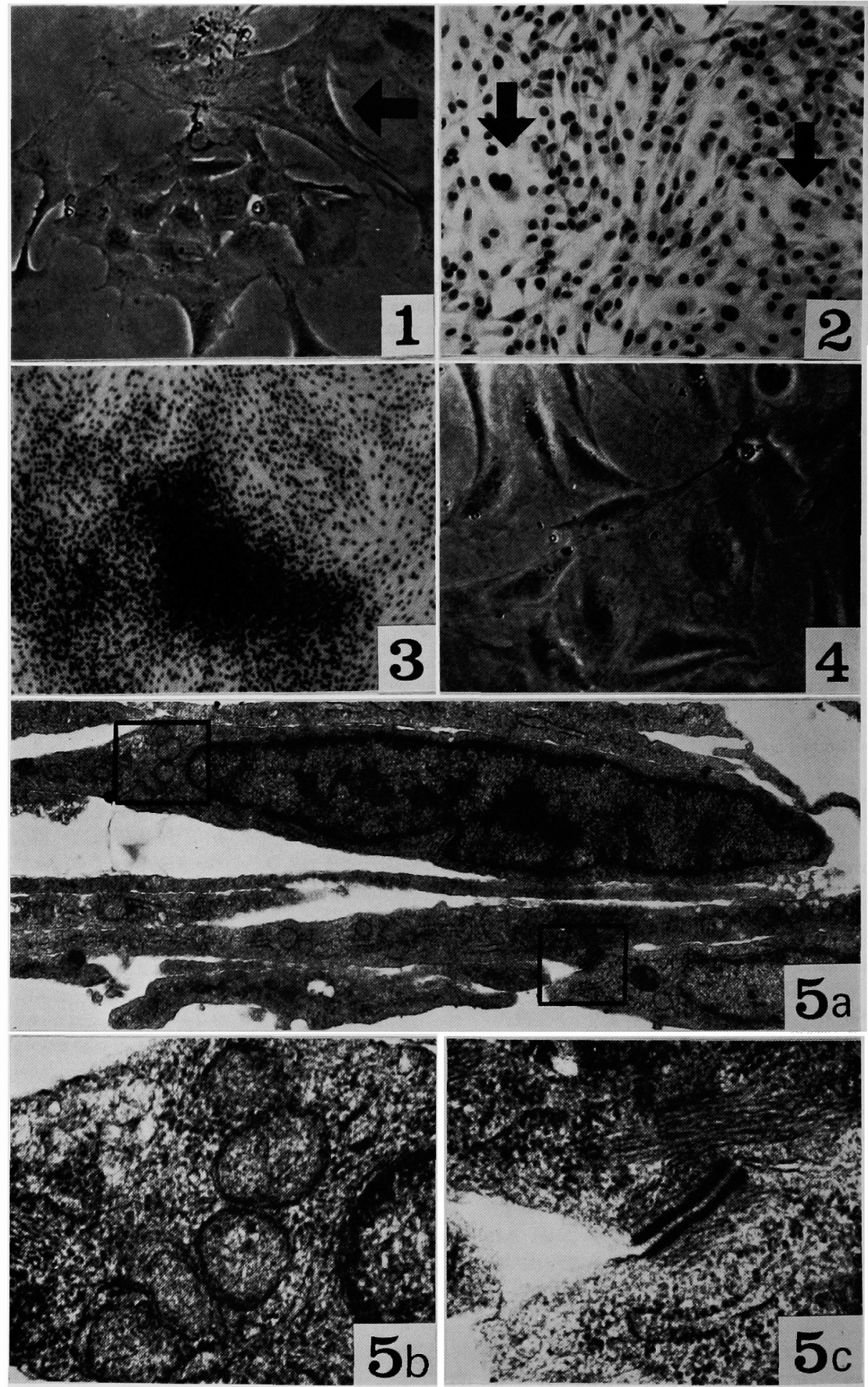


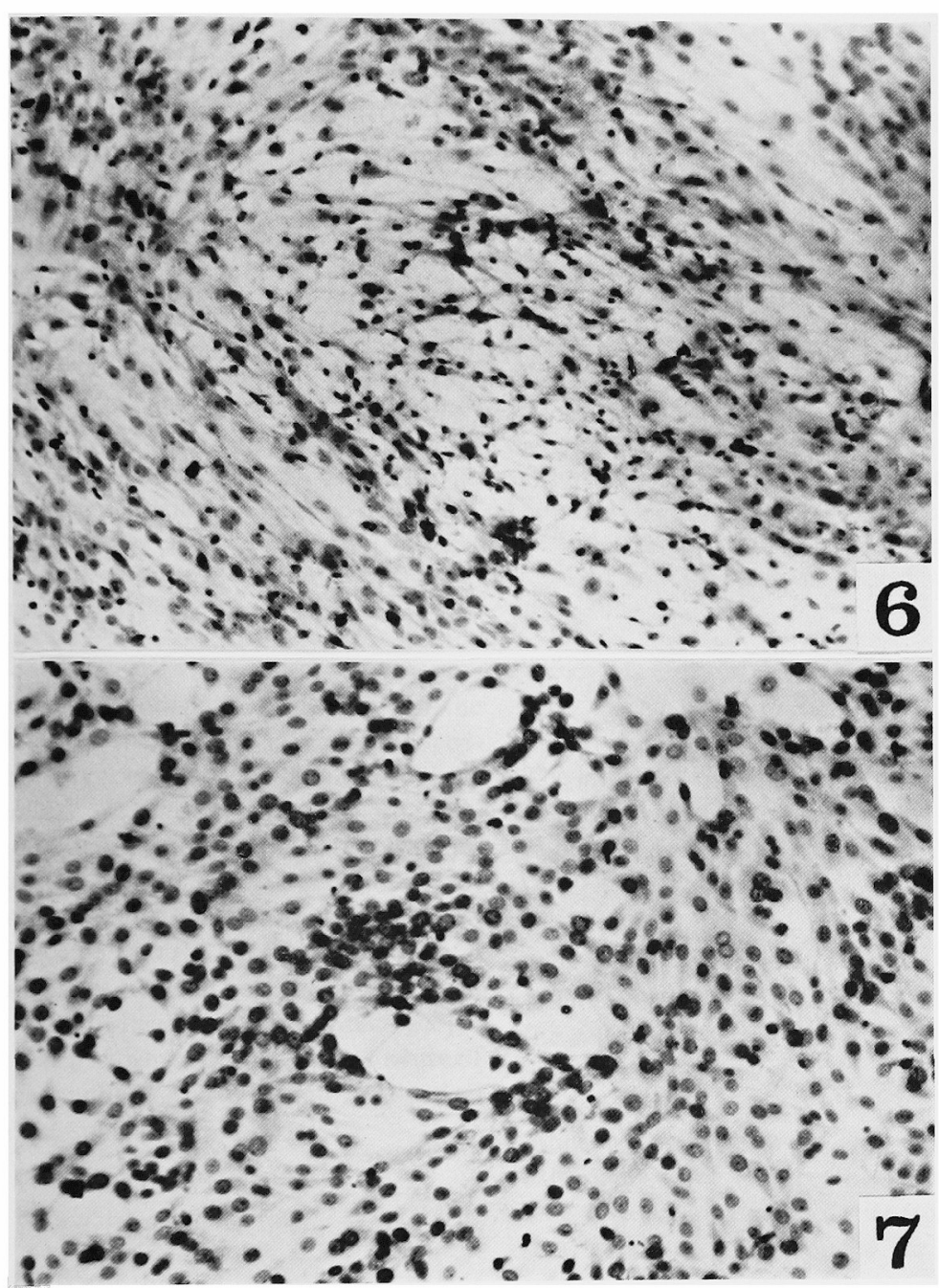

